\title{
A prospective, multi-center, observational study on the use of interferon beta-1a (Rebif) therapy in Egyptian patients with Multiple Sclerosis
}

\author{
Ahmed Nemr \\ Neurology Consultant
}

\begin{abstract}
Objective: The primary objective of this study is to describe the disease characteristics of the cohort of MS patients undergoing Rebif treatment.
\end{abstract}

Design: This is a multicentre, open label, non comparative, non randomized study conducted in Egypt on the use of interferon beta-1a (Rebif) therapy in Egyptian patients with relapsing multiple sclerosis according to McDonald criteria.

Subjects: Egyptian patients with relapsing multiple sclerosis who are naïve to interferon and are 18 to 65 years old.

Settings: A total number of 36 patients were enrolled.

Main Outcome Measures: include the mean number of relapses, time from diagnosis to start of treatment, number of relapses prior to start of treatment, annualized relapse rate, incidence of adverse events associated with Rebif therapy and number and location of lesions in MRI.

Results: 7 patients were excluded from Intention-to-Treat Population as they were enrolled regardless of the inclusion/exclusion criteria. Therefore, the Per Protocol Population included 29 patients including 11 males and 18 females and with a mean age of 31.41 years old. The number of reported relapses was 4.3 and 11 at visit 1 , visit 2 and end of the study respectively. Despite this increase, only 13 out of 29 patients $(44.83 \%-95 \%$ CI: $28.4 \%$ to $62.4 \%$ ) had relapse attacks during the study (48 weeks). The annualized relapse rate was $0.79 \pm 0.41$ (95\% CI) relapse per year. 9 patients out of 36 patients (25\% - 95\%CI: 13.75 to $41.07 \%$ ) in the safety population had adverse events during the study. 2 were reported at baseline, 5 at visit 1,1 at visit two and 1 at visit 3 . The adverse events were elevated liver enzymes (2), depression (2), injection site pain (1), allergic skin reaction (2) and flu like symptoms (1).

Conclusion: Compared to previously reported results, this study indicates that Rebif appears to have a favorable efficacy profile as well as a favorable safety profile in delaying MS progression in Egyptian patients.

Keywords: Multiple Sclerosis, Interferon, Rebif ${ }^{\circledR}$.

\section{Introduction}

Multiple Sclerosis is considered to be a chronic autoimmune disease of the central nervous system. It leads to multifocal inflammation, demyelination and axonal damage of neurons. The etiology is believed to include several factors such as genetic background, exposure to environmental pathogenic triggers (e.g.: viral infections) and the development of an immune response directed against the central nervous system.

Of the four different sub-types of MS, the relapsing-remitting form (RRMS) is the most 
common (85-90\% of patients). RRMS is characterized by acute attacks, followed by full or partial recovery, with periods of clinical silence between the relapses. In time the RRMS can progress into a secondary progressive disease course, which occurs in approximately 50\% of RRMS patients after 10 years. This stage is defined by disease progression with possible relapses and minor remissions.

Rate and severity of relapses, as well as the progression of disability are clinical endpoints of primary interest for the evaluation of disease activity.

Next to clinical manifestations of the disease, the MRI is an important objective measure to determine disease activity, even at a subclinical level. Magnetic Resonance Imaging (MRI) Gadolinium enhancement in T1 scans, number and volume of lesion in $\mathrm{T} 1$ and $\mathrm{T} 2$ scans play a significant role in the diagnosis of MS according to the revised McDonald criteria-2005. In summary, combining clinical and MRI assessment will allow selection of patients to be treated with agents known to present a favorable effect in the course of the disease.

\section{Disease Modifying Drugs (DMDs) and \\ Interferon beta -1a treatment}

The disease-modifying therapies for MS, aim to slow down the disease process and consequent damage to central nervous system. Interferon beta (IFN beta) and glatiramer acetate (GA) have been approved for the treatment of RRMS.

There are currently 3 preparations of IFN beta licensed for the treatment of MS. Two are formulations of IFN beta-1a, one administered at a dosage of 22 or $44 \mathrm{mcg}$ subcutaneous (SC) three times a week (tiw) $\left(\right.$ Rebif $\left.^{\circledR}\right)$ and the other administered at a dosage of $30 \mathrm{mcg}$ intramuscular (IM) once weekly (qwk). The third is IFN beta-1b, administered at a dosage of $250 \mu \mathrm{g}$ SC every other day (qod) (2).

Clinical trials with Rebif ${ }^{\circledR}$ (the previous formulation) have demonstrated significant therapeutic effects throughout the course of the disease, such as: reduction in relapse rate and severity, increase of the time to next relapse, increase of relapse free patients, increase of the time to sustained disability progression and finally a decreased number of patients which progressed to the secondary progressive Multiple Sclerosis (SPMS) stage Furthermore, MRI benefits have also been demonstrated, such as decrease in MRI lesions (number and size) and decrease of the burden of disease (total lesion volume).

\section{Rationale}

A treatment can be very effective, but especially in chronic illnesses, therapeutic effects can be determined by treatment adherence. Therefore, adherence to a long-term treatment is crucial for an optimal therapeutic effect. Reduced adherence to medications may be due to patients' expectations of efficacy and the incidence of Adverse Drug Reactions (ADRs) $(1,2)$. A study of adherence during the first 4 months of IFN beta-1a therapy in 80 patients with MS reported that discontinuation of treatment (nine patients) was significantly related to increases in patient reports of tingling, numbness or loss of feeling ${ }^{3}$. Patient-reported increase in fatigue, fever and asthenia were also associated with drug discontinuation (3).

Gottberg et al. (2000) demonstrated that the most frequently reported local-tissue ADRs associated with IFN beta are injection-site erythema and pain at the injection site (4). Discomfort during and after injections contributes to treatment dissatisfaction and is likely to decrease adherence $(1,5)$. Effective patient education, prophylaxis and symptom relief 
may improve adherence by reducing the incidence and severity of ADRs (6-8). Furthermore, advances in injection technology (e.g. the introduction of auto-injectors) have increased adherence and patient satisfaction $(5,9)$.

Ultimately treatment adherence would be best achieved by directly reducing the number of ADRs associated with treatment. Thus, improving tolerability provides a rationale to explore different formulations of IFN beta that are less likely to elicit these reactions.

To improve tolerability, Rebif ${ }^{\circledR}$ was developed by assessing and refining the physico-chemical integrity and injection tolerability of candidate formulations. During the research program that led to the development of Rebif ${ }^{\circledR}$, candidate vehicles were considered, and the pharmacokinetics and tolerability of candidate formulations were assessed in animal models and healthy volunteers. Notably, the final formulation of Rebif $^{\circledR}$ was developed without the addition of human serum albumin (HSA) as an excipient or the use of fetal bovine serum (FBS) during production. Studies with the use of Rebif ${ }^{\circledR}$ demonstrate a 3 -fold reduction in injection site reactions (10).

The rationale of this study is to assess the safety profile, efficacy and adherence to Rebif® in real life settings with a multinational approach, as well as the impact of this improved formulation (with regards to AEs) to patients' adherence.

\section{METHODS}

\section{Setting and Recruitment}

This is an observational study conducted in Egypt in two sites. The study was expected to enroll 45 patients who were diagnosed with Multiple Sclerosis according to McDonald criteria, with18 to 65 years of age and naïve to IFN therapy.

The study is expected to take a period of 1 year and 4 months with an enrollment period of 4 months. Each patient will be observed for 1 year. The study visits include a baseline visit (day 1) and 3 follow-up visits at months 3,6 and 12. Follow-up visits will take place in a time window of \pm 3 weeks.

\section{Inclusion criteria}

- Multiple sclerosis diagnosis according to McDonald criteria (2005).

- 18 to 65 years of age.

- Decision by treating physician to prescribe Rebif for the treatment of RMS prior to study entry.

- Naive patients to IFN.

- Willing and able to participate in the observational study program and having signed the informed consent form.

\section{Exclusion criteria}

- Have any disease other than RMS that could better explain his/her signs and symptoms.

- Have contra-indications to IFN beta-1a as defined in SPC.

- Suffer from dementia.

- Suffer from major medical or psychiatric illness.

- Pregnant and Breast Feeding women.

\section{Study Procedures}

Evaluation will be performed to assess the eligibility of the patient at inclusion.

The potential subjects will have been prescribed Rebif for the first time by their treating physicians and will then be given the option to enter in this observational study. As this is purely an observational study, the patients will be followed by their treating physicians, according to current medical practice and Rebif treatment requirements. The following visits will be documented: Baseline (day 1), month 3, month 6 and month 12. During 
A prospective, multi-center, observational study on the use of interferon beta-1a ....

each visit clinical and safety data will be recorded including demographic information, vital signs, physical examination, EDSS score, Rebif therapy including dosage, neurological examination, adverse events and concomitant medications.

\section{Statistical Analysis}

All data will be evaluated descriptively by means of mean, median, standard deviation and extreme values for continuous variables, and counts and percentages for categorical variables. All statistical tests will be exploratory.

Categorical variables will be presented in frequency tables, a 95\% confidence interval (CI) will be determined. Data on percentage of missed injections and reasons for missed injections will only be presented descriptively.

Data on number of relapses will be analyzed in different subpopulations such as high or lower dosing, highly and not highly adherent patients etc. It is not expected that the number of relapses follow the normal distribution, so the comparisons will be probably made using non-parametric tests such as signed rank test or Mann Whitney test.

The proportion of adverse events or the reasons for missed injections will be presented in frequency distribution tables.

Safety Analysis will be done on the safety population that will include all patients who have received at least 1 injection after enrollment.

\section{RESULTS}

\section{Demography and Baseline Characteristics}

The Per Protocol population included 29 patients. Their categorical baseline demographic characteristics are presented in Table 5 while their continuous baseline characteristics are presented in Table 4.

Only one patient $(3.45 \%)$ had history of autoimmune disease (rheumatoid arthritis). In addition, 10 patients out of 29 patients (34.48\%) had a total of 15 past or ongoing medical conditions. 6 were neurological, 3 were psychological/psychiatric, 3 were cardiovascular, 1 was genitourinary, 1 was metabolic/endocrine and 1 was musculoskeletal. The conditions are listed in Table1.

Analysis of the first demyelinating event revealed seven major categories for first demyelinating events. The categories and their frequencies are listed in Table 2. Vision Problems was the most prevailing category and included "Blurred Vision" (15 mentions), Diplopia (4 mentions), Optic Neuritis (1 mention) and Nystagmus (1 mention). The category "Others" included depression (1 mention), headache (1 mention) and disequilibrium (1 mention). All first demyelinating events were resolved at the time of their occurrence. There were 49 major affected neurological functions reported for the 29 patients in the intention-to-treat population. The function reported and their frequencies are listed in Table 3. Only one event was classified as monofocal while 28 events were classified as multifocal.

Regarding the number of MS relapse attacks that patients had over the last year, 9 patients had no relapse attacks. The average number of relapses was 0.97 with a standard deviation of 0.87 , a minimum of 1 attack, maximum of 3 attacks and a median of 1 attack.

\section{Number of Relapse Attacks while Patients were on Study Drug}

Table 6 shows categorical changes in frequency of attacks during the study.

There was an increase of $25.5 \%$ in frequency of clinical attacks reported between visits 3 and 2 and those reported between visits 1 and baseline visit. This corresponds to an odds ratio of 4.0441 with $95 \%$ confidence interval of $1.1025-14.8346$. A 
chi-square test shows that changes in relapse attack frequencies shown in the table above are statistically significant $(p$-value $=0.0139)$.

\section{Time from diagnosis to start of treatment}

For all 29 patients in the intention-to-treat population, the time from diagnosis to start of treatment ranged between 2 years at the maximum and few days at minimum. Table 7 shows the periods reported and their frequencies.

\section{Number of relapses prior to start of treatment}

For all 29 patients in the intention-to-treat population, the number of relapses prior to start of treatment ranged from 0 relapses to 4 relapses. The number of relapses reported and their frequencies are listed in Table 8.

\section{Annualized Relapse Rate}

13 out of 29 patients had relapse attacks during the study ( $44.83 \%$ - 95\% CI: $28.4 \%$ to $62.4 \%$ ). For those 13 patients, the average number of relapses during the study was $1.77 \pm 0.56(95 \% \mathrm{CI})$ relapse with a standard deviation of 0.93 , a minimum of 1 relapse, median of 2 and maximum of 4.

Considering all 29 patients, the average number of relapses during the study was $0.79 \pm 0.41(95 \% \mathrm{CI})$ relapse per year with a standard deviation of 1.03 , a minimum and median of 0 and a maximum of 4 .

\section{Magnetic Resonance Imaging (MRI)}

At baseline, the average number of $\mathrm{T} 2$ lesions for Brain MRI was $8 \pm 0.935$ (95\% CI) lesions per patient, with a standard deviation of 2.46 a minimum of 4 , a median of 8 and a maximum of 13 . Categorically, all patients had brain T2 lesions and the total number of T2 lesions reported was 232 . Their distribution by category is listed in Table 9 .

There were no T1 lesions reported. Only 3 patients $(10.34 \%-95 \%$ CI: $3.58 \%$ to $26.39 \%)$ had brain atrophy and it was mild for all 3 patients. For spinal cord, 6 patients had T2 lesions $(20.69 \%$ - 95\% CI:
$9.85 \%$ to $38.39 \%$ ). Categorically, 1 patient had three lesions, two patients had two lesions each and 3 patients had one lesion each. 1 patient had one gadolinium-enhancing $\mathrm{T} 1$ lesion. There were no gadolinium-negative T1 lesions reported. 26 patients $(89.66 \%-95 \%$ CI: $73.61 \%$ to $96.42 \%)$ had spinal cord atrophy and all cases were mild.

At end of study (visit 3), the average number of T2 lesions for Brain MRI was $7.66 \pm 1.571(95 \% \mathrm{CI})$ lesions per patient, with a standard deviation of 4.13 a minimum of 0 , a median of 7 and a maximum of 14 . Categorically, the total number of $\mathrm{T} 2$ lesions reported was 222 . Their distribution by category is listed in Table 10. There was one Gadolinium enhancing T1 lesion reported and one new combined unique active MRI lesion. 3 of the reported lesions were enlarging compared to baseline. 5 patients $(17.24 \%$ - $95 \%$ CI: $7.6 \%$ to $34.55 \%)$ had brain atrophy. 3 patients $(10.34 \%)$ had mild brain atrophy and 2 patients $(6.9 \%)$ had moderate brain atrophy. For spinal cord, 4 patients had spinal cord T2 lesions, each of them had two lesions. There were no T1 lesions reported. 24 patients $(82.76 \%$ - 95\%CI: $65.45 \%$ to $92.4 \%$ ) had spinal cord atrophy and all cases were mild. Other findings were 5 demyelinating alpha plaques.

The change in number of brain $\mathrm{T} 2$ lesions was found to be statistically not significant $(p$-value $=0.4847$ ) using t-test. When compared by their categories (periventricular...etc.), the change in numbers of brain $\mathrm{T} 2$ lesions was also found to be not statistically significant using chi-square test ( $p$-value $=0.98$ ).

\section{Kurtzke Scale}

Kurtzke scale results were reported at baseline and at each of the study visits. The average at baseline was 3.1 and at end of study was 3.36 with an increase of 0.25 . However, a paired t-test revealed that this increase was not statistically significant 
$(\mathrm{p}$-value $=0.7486)$ and an ANOVA test showed that changes throughout the study were also statistically not significant $(\mathrm{p}$-value $=0.8181)$. Table 11 shows the descriptive statistics for Kurtzke scale at baseline, visit one, visit two and visit three.

\section{Neurological Exam}

Tables 12 and 13 show the results for neurological exam and syndromic diagnosis in all study visits. There was statistically significant difference in the frequencies in any of the categories of exam/diagnosis throughout the study.

\section{Physician's Global Assessment of Efficacy}

For the 29 patients in the Intention-to-treat population, Physician's Global Assessment of Efficacy was "very good" for 12 patients (41.28\%), good for 9 patients $(31.03 \%)$ and Fair for 8 patients (27.59\%). There were no patients whose efficacy assessment was rather insufficient.

\section{Adverse Events}

9 patients out of 36 patients (25\% - 95\%CI: 13.75 to $41.07 \%$ ) in the safety population had adverse events during the study. 2 were reported at baseline, 5 at visit 1,1 at visit two and 1 at visit 3 . The adverse events were elevated liver enzymes (2), depression (2), injection site pain (1), allergic skin reaction (2) and flu like symptoms (1). The severity was moderate for six adverse events and mild for three. No action was taken for 6 of the adverse events, for two adverse events the study drug dose was reduced and for one the study drug was stopped. Two adverse events were possibly related to the study drug, two were probably related and 4 were definitely related. Relation to study drug was not reported for one adverse event. The status for five adverse events was stabilization, and was ongoing for two and not reported for two.

Adverse Events that have been reported to be related to the study drug were: Allergic skin reaction
(Probably related) and elevation of liver enzymes (Definitely related)

There were no serious adverse events or deaths reported throughout the study.

\section{Concomitant Medications}

There were 35 concomitant medications reported during the study. The most common medication was pregabalin $(\mathrm{n}=4,11.8 \%$ of reported concomitant medications), followed by Kemadrin ( $n=3,8.8 \%$ of reported concomitant medications). 32 of the reported concomitant medications were ongoing at the end of the study $(91.43 \%$ of reported medications) while only 3 were not ongoing at the end of the study ( $8.57 \%$ of reported medications). There were no patients who were on INF at baseline visit.

14 of the reported concomitant medications were present at start of study before allocation to the study medication. (40\% of reported concomitant medications)

There were only 33 reasons reported for concomitant medications. The leading reasons were Depression and Extrapyramidal Symptoms $(n=4$ each, $12.1 \%$ of reasons reported).

Table 14 lists all the reasons reported while Table 15 lists all concomitant medications that can lead to GI complications.

\section{Changes in Vital Signs throughout the Study}

$\underline{\text { Blood Pressure }}$

Systolic and Diastolic blood pressure data for the safety population for all study visits are shown in tables 16 and 17 respectively. ANOVA analysis shows that there was no statistically significant change in systolic and diastolic blood pressure throughout the study.

$\underline{\text { Pulse }}$

Pulse data for the safety population for all study visits are shown in table 18. ANOVA analysis shows 
that there was no statistically significant change in pulse throughout the study.

\section{Temperature}

Temperature data for the safety population for all study visits are shown in table 19.

\section{Study Drug Treatment Exposure Dosage}

Table 20 shows summary statistics for administered Rebif dosage. 3 patients were non-compliant, one of which was non-compliant in two visits. One patient was non-compliant due to burning sensation at the site of injection.

\section{Global Assessment of Tolerability}

The study drug tolerability was assessed for 18 patients to be Excellent (62.07\%), for 11 patients to be Good (37.93\%), Fair for 7 patients (24.12\%) and Poor for none.

\section{DISCUSSION}

The aim of this study was to assess the efficacy of Rebif with the primary endpoint being the mean number of relapses during the study. The number of reported relapses was 4,3 and 11 at visit 1 , visit 2 and end of the study respectively. This corresponds to a statistically significant increase in percentage of patients who had relapses from visit 1 to visit 3 . Despite this increase, only 13 out of 29 patients (44.83\% - 95\% CI: $28.4 \%$ to $62.4 \%)$ had relapse attacks during the study (48 weeks), with the mean number of relapses per patient for the intention-totreat being $0.79 \pm 0.41(95 \% \mathrm{CI})$ during the study period. This shows a considerably less relapse rate than that reported for other MS treatments like Natalizumab. In addition, the proportion of patients having relapses during the study was comparable to previously reported values for Rebif.

Regarding MRI, the average number of $\mathrm{T} 2$ brain lesions reported was $7.66 \pm 1.571$ at end of study compared to 8 at beginning of study. In total, 232 lesions were reported in baseline visits against 222 lesions in last visit. In addition, the number of patients with reported $\mathrm{T} 2$ lesions in the spinal cord was 6 in the baseline visit and 4 in the final visit. Although this decrease was not found to be statistically significant, it indicates favorable outcome in delaying the progression of disease.

In addition, there was no statistically significant change in Kurtzke score throughout the study. This can also be considered a favorable outcome regarding slowing down the progression of MS and agrees with results previously reported for other treatments like Avonex.

Finally, physician's global assessment of efficacy was mainly favorable with no patient reported as having rather insufficient efficacy.

Regarding safety, 25\% (95\%CI: 13.75 to $41.07 \%$ ) of patients in the safety population had adverse events with the one most prevalent being depression and elevated liver enzymes. This percentage of incidence of adverse events is considerably less than that previously reported for Rebif.

Finally, there was no statistically significant change in any of the vital signs throughout the study. Furthermore, the physician's global assessment of tolerability was largely favorable with none of the patients reported to have poor tolerability.

These findings combined indicate that Rebif is an effective treatment for MS that has a success rate in delaying progression of disease that is better (or at least similar) to that of other treatments. Rebif appears to be safe in Egyptian patients compared to its profile in other populations.

\section{CONCLUSION}

Compared to previously reported results, this study indicates that Rebif appears to have a favorable 
efficacy profile as well as a favorable safety profile

Table 1. Past or ongoing medical conditions in baseline visit

\begin{tabular}{|l|ll|}
\hline $\begin{array}{l}\text { Past or ongoing } \\
\text { medical conditions }\end{array}$ & Count & $\begin{array}{l}\text { \% to Sample } \\
\text { Size }\end{array}$ \\
\hline Multiple Sclerosis & 2 & $6.90 \%$ \\
Depression & 2 & $6.90 \%$ \\
Epilepsy & 2 & $6.90 \%$ \\
Diabetes Mellitus & 1 & $3.45 \%$ \\
Hypertension & 1 & $3.45 \%$ \\
Cerebral Atrophy & 1 & $3.45 \%$ \\
Tachycardia & 1 & $3.45 \%$ \\
Myasthenia Gravis & 1 & $3.45 \%$ \\
Depressive Psychosis & 1 & $3.45 \%$ \\
Hesitancy & 1 & $3.45 \%$ \\
Extrapyramidal & 1 & $3.45 \%$ \\
Symptoms & 1 & $3.45 \%$ \\
Rheumatoid Activity & 1 & \\
\hline
\end{tabular}

Table 2. Categories of First Demyelinating Event

\begin{tabular}{|c|c|c|}
\hline Category & Count & $\begin{array}{c}\% \text { to } \\
\text { Patients }\end{array}$ \\
\hline Vision Problems & 21 & $72.41 \%$ \\
\hline $\begin{array}{r}\text { Tingling / } \\
\text { Numbness }\end{array}$ & 17 & $58.62 \%$ \\
\hline Fatigue & 10 & $34.48 \%$ \\
\hline Difficulty Walking & 8 & $27.59 \%$ \\
\hline $\begin{array}{r}\text { Paralysis / } \\
\text { Movement } \\
\text { Problems }\end{array}$ & 6 & $20.69 \%$ \\
\hline Others & 3 & $10.34 \%$ \\
\hline Urine Incontinence & 3 & $10.34 \%$ \\
\hline
\end{tabular}

Table 3. Major affected organs in first demyelinating events

\begin{tabular}{|r|cc|}
\hline Organ/System & Count & $\begin{array}{c}\text { \% to } \\
\text { Patients }\end{array}$ \\
\hline $\begin{array}{r}\text { Sensory Function } \\
\text { Pyramidal }\end{array}$ & 17 & $58.62 \%$ \\
Function & 15 & $51.72 \%$ \\
Cerebral Function & 8 & $27.59 \%$ \\
Spinal Cord & 6 & $20.69 \%$ \\
Function & 2 & $6.90 \%$ \\
Visual Function & 1 & $3.45 \%$ \\
Brainstem & 1 & $3.45 \%$ \\
\hline
\end{tabular}

in delaying MS progression in Egyptian patients.

Table 4. Baseline and demographical continuous variables

\begin{tabular}{|ll|llll|}
\hline Variable & Base & $\begin{array}{l}\text { Min } \\
\text {. }\end{array}$ & $\begin{array}{l}\text { Me } \\
\text { dian }\end{array}$ & Max. & Mean \\
\hline $\begin{array}{l}\text { Weight } \\
\text { (Kg) }\end{array}$ & 29 & 48 & 72 & 100 & 72.93 \\
$\begin{array}{l}\text { Age (years) } \\
\text { Height (cm) }\end{array}$ & 29 & 20 & 28 & 51 & 31.41 \\
$\begin{array}{l}\text { SBP } \\
\text { (mmHg) }\end{array}$ & 29 & 155 & 168 & 184 & 166.9 \\
$\begin{array}{l}\text { DBP } \\
\text { (mmHg) }\end{array}$ & 29 & 60 & 80 & 90 & 77.07 \\
$\begin{array}{l}\text { Pulse(bpm) } \\
\text { Temperatur }\end{array}$ & 29 & 70 & 76 & 90 & 76.45 \\
e('C) & 29 & 37 & 37 & 37 & 37 \\
\hline
\end{tabular}

Table 5. Categorical Demographic and Baseline Variables

\begin{tabular}{|c|c|c|c|}
\hline & Base & Count & $\%$ \\
\hline Gender & Male & 11 & $37.93 \%$ \\
\hline $\mathbf{N}=\mathbf{2 9}$ & Female & 18 & $62.07 \%$ \\
\hline Race & Caucasian & 29 & $100 \%$ \\
\hline \multirow[t]{3}{*}{$\mathbf{N}=\mathbf{2 9}$} & Black & 0 & $0 \%$ \\
\hline & Asian & 0 & $0 \%$ \\
\hline & Other & 0 & $0 \%$ \\
\hline Subject & Yes & 0 & $0 \%$ \\
\hline $\begin{array}{l}\text { History of } \\
\text { Autoimmune } \\
\text { Disease } \\
\mathbf{N}=\mathbf{2 9}\end{array}$ & No & 29 & $100 \%$ \\
\hline $\begin{array}{l}\text { Family } \\
\text { History of }\end{array}$ & Yes & $\begin{array}{l}\text { 1(Rheumatoid } \\
\text { Arthritis) }\end{array}$ & $3.45 \%$ \\
\hline $\begin{array}{l}\text { Autoimmune } \\
\text { Disease } \\
\mathbf{N}=\mathbf{2 9}\end{array}$ & No & 28 & $96.55 \%$ \\
\hline Past or & Yes & 10 & $34.48 \%$ \\
\hline $\begin{array}{l}\text { Ongoing } \\
\text { Medical } \\
\text { Conditions } \\
\mathbf{N}=\mathbf{2 9}\end{array}$ & No & 19 & $65.52 \%$ \\
\hline
\end{tabular}


Table 6. Number of Relapse attacks by visits

\begin{tabular}{|c|c|c|c|}
\hline & Visit 1 & Visit 2 & Visit 3 \\
\hline $\begin{array}{l}\text { Patients who } \\
\text { had relapse } \\
\text { attacks (n) }\end{array}$ & 4 & 3 & 11 \\
\hline $\begin{array}{l}\text { Patients who } \\
\text { had relapse } \\
\text { attacks }(\%)\end{array}$ & $\begin{array}{l}13.8 \%(95 \% \\
\text { CI: } 5.5 \%- \\
30.56 \%)\end{array}$ & $\begin{array}{l}10.3 \% \\
(95 \% \\
\text { CI: } \\
3.58 \% \text { - } \\
26.39 \% \text { ) }\end{array}$ & $\begin{array}{l}39.29 \% \\
(95 \% \\
\text { CI: } \\
23.57 \% \\
- \\
57.59 \%)\end{array}$ \\
\hline $\begin{array}{l}\text { Patients who } \\
\text { did NOT } \\
\text { have relapse } \\
\text { attacks (n) }\end{array}$ & 25 & 26 & 18 \\
\hline $\begin{array}{l}\text { Patients who } \\
\text { did NOT } \\
\text { have relapse } \\
\text { attacks }(\%)\end{array}$ & $86.2 \%$ & $89.7 \%$ & $60.71 \%$ \\
\hline
\end{tabular}

Table 7. Time from diagnosis to start of treatment

\begin{tabular}{|l|ll|}
\hline $\begin{array}{l}\text { Period from } \\
\text { diagnosis to } \\
\text { first relapse }\end{array}$ & Count & \% to Patients \\
\hline few weeks & 14 & $48.3 \%$ \\
few months & 9 & $31.0 \%$ \\
few days & 2 & $6.9 \%$ \\
2 weeks & 2 & $6.9 \%$ \\
1 year & 1 & $3.4 \%$ \\
2 years & 1 & $3.4 \%$ \\
\hline
\end{tabular}

Table 8. Number of relapses prior to start of treatment

\begin{tabular}{|l|ll|}
\hline $\begin{array}{l}\text { Number of } \\
\text { relapses prior to } \\
\text { start of } \\
\text { treatment }\end{array}$ & Count & $\begin{array}{l}\text { \% to } \\
\text { Patients }\end{array}$ \\
\hline $\mathbf{1}$ & 11 & $37.9 \%$ \\
$\mathbf{0}$ & 9 & $31.0 \%$ \\
$\mathbf{2}$ & 6 & $20.7 \%$ \\
$\mathbf{4}$ & 2 & $6.9 \%$ \\
$\mathbf{3}$ & 1 & $3.4 \%$ \\
$\mathbf{1}$ & 11 & $37.9 \%$ \\
\hline
\end{tabular}

Table 9. Brain T2 Lesions at baseline

\begin{tabular}{|l|ll|}
\hline $\begin{array}{l}\text { Brain T2 } \\
\text { Lesions }\end{array}$ & Count & $\begin{array}{l}\text { \% to } \\
\text { Lesions }\end{array}$ \\
\hline $\begin{array}{l}\text { Periventricular } \\
\text { Lesions } \\
\text { Juxtacortical } \\
\text { Lesions }\end{array}$ & 118 & $50.86 \%$ \\
$\begin{array}{l}\text { Infratentorial } \\
\text { Lesions } \\
\text { Corpus } \\
\text { Callosum } \\
\text { Lesions }\end{array}$ & 41 & $27.59 \%$ \\
\hline
\end{tabular}

Table 10. Brain $T 2$ lesions at end of study

\begin{tabular}{|l|ll|}
\hline $\begin{array}{l}\text { Brain T2 } \\
\text { Lesions }\end{array}$ & Count & \% to Lesions \\
\hline $\begin{array}{l}\text { Periventricular } \\
\text { Lesions }\end{array}$ & 114 & $49.14 \%$ \\
$\begin{array}{l}\text { Juxtacortical } \\
\text { Lesions } \\
\text { Infratentorial } \\
\begin{array}{l}\text { Lesions } \\
\text { Corpus } \\
\text { Callosum } \\
\text { Lesions }\end{array}\end{array}$ & 61 & $26.29 \%$ \\
\hline
\end{tabular}


A prospective, multi-center, observational study on the use of interferon beta-1a ....

Table 11. Kurtzke Scale Descriptive statistics

\begin{tabular}{|l|l|l|}
\hline \multicolumn{2}{|l|}{ Kurtzke Scale - Baseline } & \multicolumn{2}{l|}{ Kurtzke Scale - Visit } \\
One
\end{tabular}

Table 12. Neurological exam

\begin{tabular}{|c|c|c|c|c|c|}
\hline \multicolumn{2}{|c|}{ Neurological Exam } & \multirow{2}{*}{$\begin{array}{l}\text { Baseline } \\
26\end{array}$} & \multirow{2}{*}{$\begin{array}{l}\text { Visit } \\
\mathbf{1} \\
27\end{array}$} & \multirow{2}{*}{$\begin{array}{l}\text { Visit } \\
\mathbf{2} \\
28\end{array}$} & \multirow{2}{*}{\begin{tabular}{l|} 
Visit \\
$\mathbf{3}$ \\
28 \\
\end{tabular}} \\
\hline Cognitive & Normal & & & & \\
\hline Capacity & Abnormal & 3 & 2 & 1 & 1 \\
\hline \multirow{2}{*}{$\begin{array}{l}\text { Cranial } \\
\text { Nerves }\end{array}$} & Normal & 28 & 28 & 28 & 28 \\
\hline & Abnormal & 1 & 1 & 1 & 1 \\
\hline \multirow{2}{*}{$\begin{array}{l}\text { Muscular } \\
\text { Force - } \\
\text { Upper Limb }\end{array}$} & Normal & 15 & 17 & 18 & 18 \\
\hline & Abnormal & 14 & 12 & 11 & 11 \\
\hline \multirow{2}{*}{$\begin{array}{l}\text { Muscular } \\
\text { Force - } \\
\text { Lower Limb } \\
\end{array}$} & Normal & 15 & 16 & 16 & 16 \\
\hline & Abnormal & 14 & 13 & 13 & 13 \\
\hline \multirow{2}{*}{$\begin{array}{l}\text { Reflex - } \\
\text { Upper Limb }\end{array}$} & Normal & 19 & 20 & 20 & 17 \\
\hline & Abnormal & 10 & 9 & 9 & 12 \\
\hline \multirow{2}{*}{$\begin{array}{l}\text { Reflex - } \\
\text { Lower Limb }\end{array}$} & Normal & 18 & 17 & 18 & 17 \\
\hline & Abnormal & 11 & 12 & 11 & 12 \\
\hline \multirow{2}{*}{$\begin{array}{l}\text { Motor } \\
\text { Coordination }\end{array}$} & Normal & 18 & 18 & 18 & 17 \\
\hline & Abnormal & 11 & 11 & 11 & 12 \\
\hline \multirow{2}{*}{ Balance } & Normal & 17 & 16 & 18 & 18 \\
\hline & Abnormal & 12 & 13 & 11 & 11 \\
\hline \multirow{2}{*}{ Gait } & Normal & 18 & 18 & 18 & 17 \\
\hline & Abnormal & 11 & 11 & 11 & 12 \\
\hline \multirow{2}{*}{ Sensitivity } & Normal & 12 & 14 & 16 & 14 \\
\hline & Abnormal & 17 & 15 & 13 & 15 \\
\hline \multirow{2}{*}{$\begin{array}{l}\text { Lhermitte's } \\
\text { Sign }\end{array}$} & Normal & 28 & 28 & 28 & 28 \\
\hline & Abnormal & 1 & 1 & 1 & 1 \\
\hline
\end{tabular}


Table 13. Syndromic Diagnosis

\begin{tabular}{|l|l|l|l|l|l|}
\hline \multicolumn{2}{|l|}{ Neurological Exam } & Baseline & $\begin{array}{l}\text { Visit } \\
\mathbf{1}\end{array}$ & $\begin{array}{l}\text { Visit } \\
\mathbf{2}\end{array}$ & $\begin{array}{l}\text { Visit } \\
\mathbf{3}\end{array}$ \\
\hline $\begin{array}{l}\text { Cognitive } \\
\text { Syndrome }\end{array}$ & Normal & 29 & 29 & 29 & 29 \\
\cline { 2 - 6 } & Abnormal & 0 & 0 & 0 & 0 \\
\hline $\begin{array}{l}\text { Pyramida } \\
\text { I Deficit } \\
\text { Syndrome }\end{array}$ & Normal & 28 & 28 & 28 & 28 \\
\cline { 2 - 6 } & Abnormal & 1 & 1 & 1 & 1 \\
\hline $\begin{array}{l}\text { Pyramida } \\
\text { I }\end{array}$ & Normal & 29 & 29 & 29 & 29 \\
\cline { 2 - 6 } $\begin{array}{l}\text { Liberatio } \\
\text { n } \\
\text { Syndrome }\end{array}$ & Abnormal & 0 & 0 & 0 & 0 \\
\hline $\begin{array}{l}\text { Sensitive } \\
\text { Syndrome }\end{array}$ & Normal & 26 & 28 & 28 & 28 \\
\cline { 2 - 6 } & Abnormal & 3 & 1 & 1 & 1 \\
\hline $\begin{array}{l}\text { Cerebella } \\
\text { r } \\
\text { Sydrome }\end{array}$ & Normal & 28 & 28 & 28 & 27 \\
\cline { 2 - 6 } & Abnormal & 1 & 1 & 1 & 2 \\
\hline $\begin{array}{l}\text { Brainste } \\
\text { m } \\
\text { Syndrome }\end{array}$ & Normal & 28 & 28 & 28 & 27 \\
\cline { 2 - 6 } $\begin{array}{l}\text { Vesicle, } \\
\text { intestinal } \\
\text { I } \\
\text { Dysfuncti } \\
\text { on }\end{array}$ & Abnormal & 1 & 1 & 1 & 2 \\
\cline { 2 - 6 } & Normal & 27 & 28 & 28 & 27 \\
\hline $\begin{array}{l}\text { Visual } \\
\text { Deficit }\end{array}$ & Normal & 27 & 1 & 1 & 2 \\
\cline { 2 - 6 } & Abnormal & 2 & 28 & 28 & 27 \\
\hline \multirow{2}{*}{ Abnormal } & 2 & 1 & 2 \\
\hline
\end{tabular}

Table 14. Concomitant Medications Reasons

\begin{tabular}{|c|c|c|}
\hline Reason & Count & $\begin{array}{l}\% \text { to } \\
\text { Reasons }\end{array}$ \\
\hline Depression & 4 & $12.1 \%$ \\
\hline $\begin{array}{l}\text { Extrapyramidal } \\
\text { Symptoms }\end{array}$ & 4 & $12.1 \%$ \\
\hline Antipsychotic & 3 & $9.1 \%$ \\
\hline Epilepsy & 3 & $9.1 \%$ \\
\hline Tingling & 3 & $9.1 \%$ \\
\hline Allergy & 2 & $6.1 \%$ \\
\hline Hypertension & 2 & $6.1 \%$ \\
\hline Immunity & 2 & $6.1 \%$ \\
\hline Neuropathy & 2 & $6.1 \%$ \\
\hline Spasticity & 2 & $6.1 \%$ \\
\hline Dyspnea & 1 & $3.0 \%$ \\
\hline Incontinence & 1 & $3.0 \%$ \\
\hline Insomnia & 1 & $3.0 \%$ \\
\hline Tachycardia & 1 & $3.0 \%$ \\
\hline Tonic & 1 & $3.0 \%$ \\
\hline $\begin{array}{l}\text { Myasthenia } \\
\text { gravis }\end{array}$ & 1 & $3.0 \%$ \\
\hline
\end{tabular}

Table 15. Concomitant Medications

\begin{tabular}{|c|c|c|}
\hline Medication & Count & $\begin{array}{l}\% \text { to } \\
\text { Medications }\end{array}$ \\
\hline Pregabalin & 4 & $11.8 \%$ \\
\hline Procyclidine & 3 & $8.8 \%$ \\
\hline Azathioprine & 2 & $5.9 \%$ \\
\hline Baclofen & 2 & $5.9 \%$ \\
\hline Paroxetine & 2 & $5.9 \%$ \\
\hline $\begin{array}{l}\text { ACE } \\
\text { inhibitor }\end{array}$ & 1 & $2.9 \%$ \\
\hline Hydroxycin & 1 & $2.9 \%$ \\
\hline Bisoprolol & 1 & $2.9 \%$ \\
\hline Clauzapine & 1 & $2.9 \%$ \\
\hline Gabapentin & 1 & $2.9 \%$ \\
\hline Mictonorm & 1 & $2.9 \%$ \\
\hline Phenytoin & 1 & $2.9 \%$ \\
\hline Pimozide & 1 & $2.9 \%$ \\
\hline Risperidone & 1 & $2.9 \%$ \\
\hline $\begin{array}{l}\text { Valproic } \\
\text { acid }\end{array}$ & 1 & $2.9 \%$ \\
\hline Furosemide & 1 & $2.9 \%$ \\
\hline Neostigmine & 1 & $2.9 \%$ \\
\hline $\begin{array}{l}\text { Co-enzyme } \\
\mathbf{Q}\end{array}$ & 1 & $2.9 \%$ \\
\hline Fluoxetine & 1 & $2.9 \%$ \\
\hline Indolol & 1 & $2.9 \%$ \\
\hline $\begin{array}{l}\text { Levocarbido } \\
\text { pa }\end{array}$ & 1 & $2.9 \%$ \\
\hline $\begin{array}{l}\text { Aminophylli } \\
\text { ne }\end{array}$ & 1 & $2.9 \%$ \\
\hline $\begin{array}{l}\text { Carbamazep } \\
\text { ine }\end{array}$ & 1 & $2.9 \%$ \\
\hline Quetiapine & 1 & $2.9 \%$ \\
\hline S-Cetyl Nor & 1 & $2.9 \%$ \\
\hline $\begin{array}{l}\text { Cetirizine } \\
\text { HCl }\end{array}$ & 1 & $2.9 \%$ \\
\hline
\end{tabular}


A prospective, multi-center, observational study on the use of interferon beta-1a ....

Table 16. SBP-Safety Population

\begin{tabular}{|c|c|c|c|c|c|c|c|}
\hline \multicolumn{2}{|c|}{ SBP - Baseline } & \multicolumn{2}{|l|}{ SBP - Visit 1} & \multicolumn{2}{|l|}{ SBP - Visit 2} & \multicolumn{2}{|c|}{ SBP - Visit 3} \\
\hline $\begin{array}{l}\text { Base (no. } \\
\text { of } \\
\text { patients) }\end{array}$ & 36 & $\begin{array}{l}\text { Base (no. of } \\
\text { patients) }\end{array}$ & 36 & $\begin{array}{l}\text { Base (no. of } \\
\text { patients) }\end{array}$ & 36 & $\begin{array}{l}\text { Base (no. of } \\
\text { patients) }\end{array}$ & 34 \\
\hline Missed & 0 & Missed & 0 & Missed & 0 & Missed & 2 \\
\hline Average & 119.86 & Average & 120.42 & Average & 119.03 & Average & 121.47 \\
\hline StdDev & 9.06 & StdDev & 8.14 & StdDev & 10.81 & StdDev & 8.21 \\
\hline Min & 100 & Min & 110 & Min & 100 & Min & 100 \\
\hline Median & 120 & Median & 120 & Median & 120 & Median & 120 \\
\hline Max & 140 & Max & 140 & Max & 140 & Max & 140 \\
\hline
\end{tabular}

Table 17. DBP-Safety Population

\begin{tabular}{|l|c|l|c|l|c|l|c|}
\hline \multicolumn{2}{|l|}{ DBP - Baseline } & \multicolumn{2}{l|l}{ DBP - Visit 1 } & \multicolumn{2}{l|}{ DBP - Visit 2 } & \multicolumn{2}{l|}{ DBP - Visit 3 } \\
\hline $\begin{array}{l}\text { Base (no. of } \\
\text { patients) }\end{array}$ & 36 & $\begin{array}{l}\text { Base (no. of } \\
\text { patients) }\end{array}$ & 36 & $\begin{array}{l}\text { Base (no. of } \\
\text { patients) }\end{array}$ & 36 & $\begin{array}{l}\text { Base (no. of } \\
\text { patients) }\end{array}$ & 34 \\
\hline Missed & 0 & Missed & 0 & Missed & 0 & Missed & 2 \\
\hline Average & 76.81 & Average & 77.78 & Average & 76.39 & Average & 78.24 \\
\hline StdDev & 6.78 & StdDev & 5.79 & StdDev & 7.03 & StdDev & 6.50 \\
\hline Min & 60 & Min & 70 & Min & 60 & Min & 60 \\
\hline Median & 80 & Median & 80 & Median & 80 & Median & 80 \\
\hline Max & 90 & Max & 90 & Max & 90 & Max & 90 \\
\hline
\end{tabular}

Table 18. Pulse-Safety Population

\begin{tabular}{|l|c|l|c|l|c|l|c|}
\hline \multicolumn{2}{|l|}{ PULSE - Baseline } & \multicolumn{2}{l|}{ PULSE - Visit 1 } & \multicolumn{2}{l|}{ PULSE - Visit 2 } & \multicolumn{2}{l|}{ PULSE - Visit 3 } \\
\hline $\begin{array}{l}\text { Base (no. of } \\
\text { patients) }\end{array}$ & 36 & $\begin{array}{l}\text { Base (no. of } \\
\text { patients) }\end{array}$ & 36 & $\begin{array}{l}\text { Base (no. of } \\
\text { patients) }\end{array}$ & 36 & $\begin{array}{l}\text { Base (no. of } \\
\text { patients) }\end{array}$ & 34 \\
\hline Missed & 0 & Missed & 0 & Missed & 0 & Missed & 2 \\
\hline Average & 75.78 & Average & 75.94 & Average & 76.14 & Average & 74.74 \\
\hline StdDev & 5.07 & StdDev & 4.16 & StdDev & 3.74 & StdDev & 3.30 \\
\hline Min & 70 & Min & 70 & Min & 70 & Min & 70 \\
\hline Median & 75 & Median & 75 & Median & 77 & Median & 75 \\
\hline Max & 90 & Max & 87 & Max & 83 & Max & 81 \\
\hline
\end{tabular}


Table 19. Temperature-Safety Population

\begin{tabular}{|l|c|l|l|l|c|l|c|}
\hline \multicolumn{2}{|l|}{$\begin{array}{l}\text { TEMPERATURE - } \\
\text { Baseline }\end{array}$} & \multicolumn{2}{l|l}{$\begin{array}{l}\text { TEMPERATURE - } \\
\text { Visit 1 }\end{array}$} & \multicolumn{2}{l|}{$\begin{array}{l}\text { TEMPERATURE - Visit } \\
\text { 2 }\end{array}$} & \multicolumn{2}{l|}{$\begin{array}{l}\text { VMPERATURE - } \\
\text { Visit 3 }\end{array}$} \\
\hline $\begin{array}{l}\text { Base (no. of } \\
\text { patients) }\end{array}$ & 36 & $\begin{array}{l}\text { Base (no. of } \\
\text { patients) }\end{array}$ & 36 & $\begin{array}{l}\text { Base (no. of } \\
\text { patients) }\end{array}$ & 36 & $\begin{array}{l}\text { Base (no. of } \\
\text { patients) }\end{array}$ & 35 \\
\hline Missed & 0 & Missed & 0 & Missed & 0 & Missed & 1 \\
\hline Average & 37.00 & Average & 37.02 & Average & 37.06 & Average & 37.04 \\
\hline StdDev & 0.00 & StdDev & 0.10 & StdDev & 0.14 & StdDev & 0.11 \\
\hline Min & 37 & Min & 37 & Min & 37 & Min & 37 \\
\hline Median & 37 & Median & 37 & Median & 37 & Median & 37 \\
\hline Max & 37 & Max & 37.5 & Max & 37.5 & Max & 37.5 \\
\hline
\end{tabular}

Table 20. Study Drug Exposure Dosage

\begin{tabular}{|c|c|c|c|c|c|c|c|c|c|}
\hline & \multicolumn{3}{|c|}{ Rebif Dose - V1 } & \multicolumn{3}{|c|}{ Rebif Dose - V2 } & \multicolumn{3}{|c|}{ Rebif Dose - V3 } \\
\hline & $\begin{array}{l}44 \mathrm{mcg} \\
\text { tiw }\end{array}$ & $\begin{array}{l}22 \mathrm{mcg} \\
\text { tiw }\end{array}$ & $\begin{array}{l}8.8 \\
\text { mcg } \\
\text { tiw }\end{array}$ & $\begin{array}{l}44 \mathrm{mcg} \\
\text { tiw }\end{array}$ & $\begin{array}{l}22 \mathrm{mcg} \\
\text { tiw }\end{array}$ & $\begin{array}{l}8.8 \\
\text { mcg } \\
\text { tiw }\end{array}$ & $\begin{array}{l}44 \mathrm{mcg} \\
\text { tiw }\end{array}$ & $\begin{array}{l}22 \text { mcg } \\
\text { tiw }\end{array}$ & $\begin{array}{l}8.8 \mathrm{mcg} \\
\text { tiw }\end{array}$ \\
\hline $\begin{array}{l}\text { Number of } \\
\text { Patients }\end{array}$ & 32 & 4 & $\mathbf{0}$ & 32 & 4 & $\mathbf{0}$ & 32 & 4 & $\mathbf{0}$ \\
\hline $\begin{array}{l}\% \text { of } \\
\text { Patients }\end{array}$ & $89 \%$ & $11 \%$ & 0\% & $89 \%$ & $11 \%$ & $0 \%$ & $89 \%$ & $11 \%$ & $0 \%$ \\
\hline
\end{tabular}

\section{REFERENCES}

1. Polman et al. (2006). A Randomized, Placebo-Controlled Trial of Natalizumab for Relapsing Multiple Sclerosis. The New England Journal of Medicine, 354:899-910

2. Etemadifar et al. (2006). Comparison of Betaferon, Avonex, and Rebif in treatment of relapsing-remitting multiple sclerosis. Acta Neurologica Scandinavic, 113(5):283-7

3. Newcombe RG (1998). Two-sided confidence intervals for the single proportion: Comparison of seven methods. Statistics in Medicine, 17: 857-872.

4. Armitage P and Berry G (1994). Statistical Methods in Medical Research (3rd ed.). London: Blackwell, pp 108-109).

5. Sandberg-Wollheim M, Bever C, Carter J, Färkkilä M, Hurwitz B, Lapierre Y, Chang P, Francis GS (2005). EVIDENCE Study Group. Comparative tolerance of IFN beta-1a regimens in patients with relapsing multiple sclerosis. The EVIDENCE study. J Neurol. 252(1):8-13.

6. Mohr DC, Goodkin DE, Likosky W, Gatto N, Neilley LK, Griffin C, Stiebling B (1996). Therapeutic expectations of patients with multiple sclerosis upon initiating interferon beta-1b: relationship to adherence to treatment. Mult Scler. 2(5):222-6.

7. Mohr DC, Likosky W, Boudewyn AC, Marietta P, Dwyer P, Van der Wende J, Goodkin DE (1998). Side effect profile and adherence to in the treatment of multiple sclerosis with interferon beta-1a. Mult Scler. 4(6):487-9.

8. Gottberg K, Gardulf A, Fredrikson S (2000). Interferon-beta treatment for patients with multiple sclerosis: the patients' perceptions of the side-effects. Mult Scler. 6(5):349-54.

9. Cramer JA, Cuffel BJ, Divan V, Al-Sabbagh A, Glassman M (2006). Patient satisfaction with an injection device for multiple sclerosis treatment. Acta Neurol Scand. 113(3):156-62.

10. Reess J, Haas J, Gabriel K, Fuhlrott A, Fiola M (2002). Both paracetamol and ibuprofen are equally effective in managing flu-like symptoms in relapsing-remitting multiple sclerosis patients during interferon beta-1a (AVONEX) therapy. Mult Scler.8(1):15-8 